\title{
Overexpression of MiR-155-5p and increased number of macrophage population in precancerous prostatic disease
}

DOI: https:// doi.org/10.22435/hsji.v11i2.3952

Rachma Greta Perdana Putri ${ }^{1}$, Sari Eka Pratiwi ${ }^{2}$, Didik Setyo Heriyanto ${ }^{3}$, Danarto ${ }^{4}$, Indwiani Astuti ${ }^{5}$, Nur Arfian $^{6}$, Sofia Mubarika Haryana ${ }^{7}$

${ }^{1}$ Department of Histology, Faculty of Medicine, Universitas Ahmad Dahlan, Yogyakarta, Indonesia.

${ }^{2}$ Department of Biology and Pathobiology, Faculty of Medicine, Universitas Tanjungpura, Pontianak, Kalimantan Barat, Indonesia.

${ }^{3}$ Department of Anatomical Pathology, Faculty of Medicine, Public Health and Nursing, Universitas Gadjah Mada, Yogyakarta, Indonesia.

${ }^{4}$ Department of Urology, Faculty of Medicine, Public Health and Nursing, and Dr. Sardjito Teaching Hospital, Yogyakarta, Indonesia.

${ }^{5}$ Department of Pharmacology and Therapy, Faculty of Medicine, Public Health and Nursing, Universitas Gadjah Mada, Yogyakarta, Indonesia.

${ }^{6}$ Department of Anatomy, Faculty of Medicine, Public Health and Nursing, Universitas Gadjah Mada, Yogyakarta, Indonesia. ${ }^{7}$ Department of Histology and Cell Biology, Faculty of Medicine, Public Health and Nursing, Universitas Gadjah Mada, Yogyakarta, Indonesia.

Corresponding author: Rachma Greta Perdana Putri

Email: rachmagreta@med.uad.ac.id

Received: August 10, 2020; Revised: December 9, 2020; Accepted: December 10, 2020

\begin{abstract}
Abstrak
Latar belakang: Gangguan regulasi mikroRNA(miR) dan inflamasi kronik dapat mengubah tumor menjadi karsinoma dan kanker dengan metastasis melalui perubahan seluler dan genomik. Lesi prekanker memiliki peluang 33,3 persen menjadi kanker. Penelitian ini bertujuan untuk mengkaji peran miR-1555 p terhadap mRNA SOCS1 dan populasi makrofag terhadap progresivitas penyakit yang berhubungan dengan Benign Prostate Hyperplasia (BPH), High Grade Prostatic Intraepithelial Neoplasia (HGPIN), dan Prostate Adenocarcinoma (PRAD).
\end{abstract}

Metode : Penelitian ini merupakan penelitian potong lintang dengan 3 kelompok, yaitu BPH,HGPIN, dan PRAD. Sampel jaringan didapatkan dari Tindakan TURP. Ekspresi miR-155 dianalisis menggunakan qPCR dan dikalkulasi menggunakan metode Livak. Ekspresi mRNA SOCS-1 dianalisis menggunakan reverse transcriptase PCR. Penanda pan makrofag, anti CD-68 monoclonal antibody(MoAb) digunakan untuk mendeteksi populasi makrofag pada jaringan dengan imunohistokimia.

Hasil : Ekspresi miR-155 lebih tinggi pada HGPIN dibandingkan BPH dan PRAD $(p=0,14)$. Ekspresi mRNA SOCS1 pada HGPIN paling rendah diantara ketiga sampel $(p=0,96)$. Terdapat korelasi negative antara miR-155 dan mRNA SOCS1 ( $p=0,02)$. Terdapat peningkatan persentase populasi makrofag yang signifikan pada HGPIN (6,03 persen) dibandingkan BPH (0.89 persen) dengan $p=0,00$.

Kesimpulan : Pada penelitian ini, terdapat perubahan persentase makrofag dan miR-155 pada HGPIN. Variasi ekspresi miR-155 dan persentase populasi makrofag dapat disebabkan karena perubahan epigenetik. Oleh sebab itu, perlu penelitian lebih lanjut untuk memvalidasi hasil tersebut dan memahami kemungkinan menjadi biomarker pada penyakit prekanker pada prostat. (Health Science Journal of Indonesia 2020;11(2):85-91)

Kata Kunci: Prostatic Intaepithelial Neoplasia, miR-155, Makrofag

\footnotetext{
Abstract

Background: Impaired microRNA(miR) regulation and chronic inflammation could transform tumors into carcinoma and cancer by metastasis through cellular and genomic changes. Precancerous lesions have a 33.3 percent chance of becoming cancerous. This study investigated the role of miR-155 related to SOCS1 mRNA and macrophage population in disease progression associated with Benign Prostate Hyperplasia (BPH), High-Grade Prostatic Intraepithelial Neoplasia (HGPIN), and Prostate Adenocarcinoma (PRAD).
} 


\begin{abstract}
Methods: This was a cross-sectional study using three groups of samples, namely BPH, HGPIN, and PRAD. Tissue samples were obtained from TURP Action. The expression of miR-155 was analyzed using real-time qPCR and calculated using the Livak method. The expression of SOCS1 mRNA was analyzed using reverse transcriptase PCR. The macrophage pan-marker, anti-CD68 monoclonal antibody (MoAb), was used to detect macrophage population in tissues by immunohistochemistry.
\end{abstract}

Results: The expression of miR-155 was higher in HGPIN than BPH and PRAD $(p=0.14)$. The expression of SOCS1 mRNA in HGPIN was the lowest among the three samples $(p=0.96)$. There was a negative correlation between miR-155 and SOCS1 mRNA $(p=0.02)$. There was a significant increase in the percentage of the macrophage population in HGPIN (6.03 percent) compared to BPH ( 0.89 percent) with $p=0.00$.

Conclusion: In this study, there were changes in the percentage of macrophage and miR-155 in HGPIN. The variation in miR-155 expression and the percentage of the macrophage may be caused by epigenetic changes. Therefore, further research is needed to validate these results and understand the possibility of being a biomarker in precancerous disease of the prostate. (Health Science Journal of Indonesia 2020;11(2):85-91)

Keywords: Prostatic Intraepithelial Neoplasia, miR-155, Macrophage

Prostate cancer (PCA) is the third-highest cancer in men according to GLOBOCAN in 2012. In Europe, the mortality rate was 94,000 in 2008 , while in the USA there were 28,000 deaths in 2012. In Indonesia, it was reported from three major cities (Jakarta, Surabaya, Bandung), the mortality rate was 1,102 patients in 2003. To date, the diagnostic tools for PCA are rectal toucher examination, detection of prostate-specific antigen (PSA) serum, and transrectal ultrasound, but PSA is ultimately not a specific biomarker because will increase for other conditions namely infection and inflammation such as prostatitis. There are several types of prostate cancer and the most common type of PCA is prostate adenocarcinoma (PRAD). Assessment of disease progression using the Gleason score is based on histopathological features. ${ }^{1}$

Benign prostate hyperplasia $(\mathrm{BPH})$ is hyperplasia in the transition zone of the prostate. The risk of $\mathrm{BPH}$ emergence was related to chronic inflammation. Chronic inflammation can play a role in carcinogenesis by cellular and genomic changes. ${ }^{2}$ Prostatic intraepithelial neoplasia (PIN) is an abnormal progression into atypical cell formation. It is classified into low-grade PIN and high-grade PIN. High-grade PIN (HGPIN) occurs in the peripheral zone of the prostate with a 33.3 percent chance of becoming cancer. ${ }^{3}$ Cancer progress is not only regulated by genetic factors and epigenetic factors, but also chronic inflammation that can affect carcinogenesis. ${ }^{4}$

Macrophages located in the tumor area are called tumor-associated macrophages, which function in increased angiogenesis and metastasis. Macrophages are polarized into M1 (classically activated macrophage) as a proinflammatory response, and
M2 (alternatively activated macrophage), which are influenced by cytokines released by cells. M1 macrophages related to bacterial infection responses secrete nitric oxide, Interluekin-12 (IL-12), IL-23, and tumor necrosis factor-alpha (TNF- $\alpha$ ). In cancer, M1 is responsible for identifying and eradicating cancer cells and provides a good prognosis. Macrophage type M2 is an anti-inflammatory response that releases IL-10, IL-13, IL-6, TGF $\beta$, and vascular endothelial growth factor-beta (VEGF), which play a role in angiogenesis, tissue remodeling, and are related to therapy resistance and poorer prognosis. ${ }^{5,6}$ The anti-CD68 monoclonal antibody is a marker for pan macrophage. ${ }^{7,8}$ It can be observed in human BPH tissue and is involved in the growth and progression of BPH by an unknown mechanism. ${ }^{2}$

The histopathological features of HGPIN are characterized by abnormal development of epithelial lining of the prostate acini and duct, followed by secretion of cytokines and chemokines from macrophage surrounding the prostate epithelial cells. Further, macrophage could be polarized into pro-inflammatory or anti-inflammatory. ${ }^{9}$ There are also prominent nucleoli and reactive atypia due to inflammation, metaplasia, and hyperplasia in HGPIN .10

MicroRNA (miR) are small non-coding RNA consisting of 18-25 nucleotides that regulate gene expression and are stable under a variety of conditions. MicroRNA control messenger RNA (mRNA) stability and target mRNA translation in the 3'untranslated region from noncoding RNA and convert tumor expression to cancer and metastatic cancer. ${ }^{11}$ MicroRNA-155 can induce the activation of this role in the conversion of macrophage to M1 by degraded SOCS1 (suppressor of cytokine 
signaling). ${ }^{12}$ This study investigated the role of miR-155 related to SOCS1 mRNA and macrophage populations in the disease progression related to $\mathrm{BPH}, \mathrm{HGPIN}$, and PRAD.

\section{METHODS}

\section{Sample collection}

This research was a cross-sectional study using Formalin-Fixed Paraffin-Embedded (FFPE) tissue samples provided by a private laboratory, histopathologically confirmed as BPH, HGPIN, and PRAD with a total of 30 samples. Each of the 10 samples represents one of the three sample types. Tissue samples were collected from the Transurethral Resection Prostate (TURP) which had been processed into FFPE. This study was approved by the Medical and Health Research Ethics Committee, Faculty of Medicine, Public Health and Nursing, Universitas Gadjah Mada (Ref: KE/FK/0888/EC/2018).

\section{RNA isolation from FFPE tissue}

Four sections of four micrometers $(16 \mu \mathrm{m})$ FFPE tissue were used to extract the total RNA. Isolation of RNA using the miRNeasy FFPE Kit, cat. no. 217504 (Qiagen, Germany). The tissue was deparaffinized using xylene, centrifuged at 10,000 RPM for 4 minutes then continued at 12,0000 RPM for 3 minutes to bring the sample to the bottom of the tube. The samples were further analyzed using the protocol from miRNeasy FFPE Kit. MiRNeasy FFPE Kit can effectively purify microRNA and total RNA from FFPE tissue portion. The concentration of total RNA was measured using a Nanovue Plus Spectrophotometer (GE Healthcare Life Science). Total RNA was stored at $-80^{\circ} \mathrm{C}$ until use.

\section{Real-Time Quantitative PCR}

Quantification of miR-155 expression in the FFPE tissue using Quantitative real-time PCR in duplicate. Synthesis of cDNA using miRCURY LNA RT Kit (cat.no. 339340, Qiagen) according to the procedure in the kit. Syber green for qPCR is used with miRCURY SYBR Green PCR Kit (cat.no. 339345, Qiagen). The primer sequence for miR-155 was 5'- UUAAUGCUAAUCGUGAUAGGGGU-3' and U6 is 5'- CGCTTCGGCAGCACATATACTA-3'. Samples were run on a real-time Biorad Thermal cycler CFX 96 (Biorad, USA) system. Relative quantification for the miR-155 expression used the
Livak method, and U6 was used as the reference gene. All of these samples were standardized with reference genes.

\section{Reverse Transcriptase PCR}

SOCS1 mRNA analysis used reverse transcriptase PCR with Select cyclerTM II Thermal cycler. Synthesis of cDNA SOCS1 mRNA used ReverTra Ace ${ }^{\circledR} \mathrm{qPCR}$ RT Master Mix with gDNA Remover (cat. no. FSQ-301, TOYOBO) and SYBR Green GoTaq ${ }^{\circledR}$ Green Master Mix (cat.no. M7122, Promega) with the protocol as described in the kit, using cDNA template 3 ul. Primer sequences for SOCS1 mRNA are: forward 5'- GACGCCTGCGGATTCTACTG-3', and SOCS1 mRNAreverse 5'-AGGCCATCTTCACGCTAAGG-3', and primer sequencesforbeta-ActinmRNAwere: forward 5'-CGCGAGAAGATGACCCAGATC-3' beta-Actin mRNA Reverse 5'-TCACCGGAGTCCATCACGA-3'. The annealing temperature for SOCS1 was $60^{\circ} \mathrm{C}$ and for beta-Actin was $56^{\circ} \mathrm{C}$. After electrophoresis of PCR product then pictures were taken for mRNA band using gel doc G:BOX Chemi $\mathrm{XRQ}^{\circledR}$ and quantified using ImageJ.

\section{Immunohistochemistry}

The sections were separated into three alterations of fresh xylene for 5 minutes each followed by dehydration in a series of absolute alcohol for 2 minutes each. Antigen retrieval was done by heating for 15 minutes in a citrate buffer solution. The system was allowed to cool to room temperature and then the slides were washed with Phosphate Buffer Saline (PBS) for 5 minutes. Endogenous peroxidase was blocked with $3 \% \mathrm{H}_{2} \mathrm{O}_{2}$ for 5 minutes at room temperature. The slides were then washed with PBS for 5 minutes. To block endogenous biotin, the sections were incubated with a blocking agent (Background Sniper, Starr Trek Universal HRP Detection, BioCare Medical) for 20 minutes, using parafilm. Then, the sections were incubated with a primary anti-CD68 monoclonal antibody (Abcam), concentration 1:400, and covered with parafilm overnight at temperature $4^{\circ} \mathrm{C}$. The next day, the slides were put at room temperature for 30 minutes and washed with PBS. To further enhance staining, the sections were then incubated with secondary antibody (Trekkie Universal Link, Starr Trek Universal HRP Detection, BioCare Medical) using parafilm for 60 minutes followed by three consecutive buffer washes (PBS), each for 5 minutes. Avidin-Horseradish peroxidase tracks (Starr Trek Universal HRP Detection, BioCare Medical) were 
added to the sections and incubated for 45 minutes using parafilm. The diaminobenzidine chromogen (Starr Trek Universal HRP Detection, BioCare Medical) was prepared just prior to use by mixing $1 \mu l$ of chromogen into $200 \mu \mathrm{l}$ of buffer in a mixing vial and later adding $100 \mu$ over the sections until the sections were brown. The sections were washed with water and counterstained with hematoxylin, dehydration, cleared, and installed. The number of macrophages was counted from 10 microscopic fields in one slide. The percentage was calculated by comparing the number of macrophages per cell population in an area multiplied by 100 percent.

\section{Data analysis}

MicroRNA expression was analyzed using BioRad CFX manager 96 software, and the differences between the three samples were analyzed using the Kruskal Wallis tests. Differences in SOCS1 mRNA expression and percentage of pan macrophages were analyzed using ANOVA and post hoc LSD. Correlation analysis used Pearson correlation tests.

\section{RESULTS}

MicoRNA-155 expression, SOCS1 mRNA expression, and negative correlation between miR-155 and SOCS1 mRNA in BPH, HGPIN, and PRAD

Relative expression for miR-155 calculation used Livak method $=2^{-\Delta \Delta \mathrm{Cq}}$. The results are shown in Figure 1 .

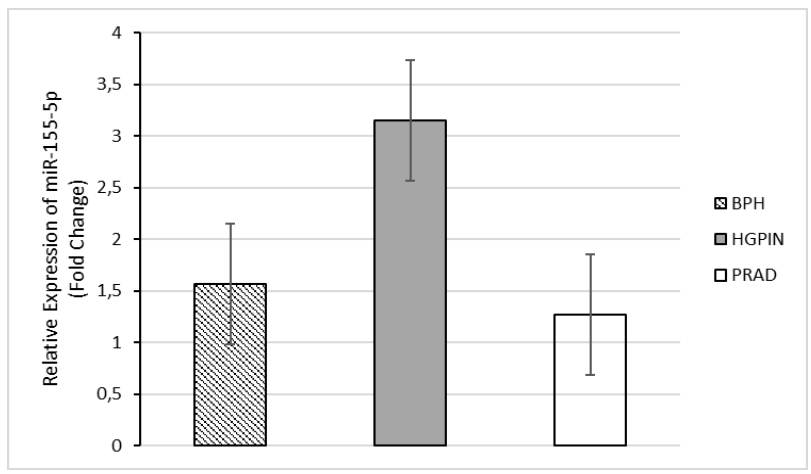

Kruskal Wallis test, $p$ significant $<0.05$

Figure 1. Averages of miR-155 expression in BPH, HGPIN, and PRAD using the Livak method.

In this study, compared to $\mathrm{BPH}$, miR-155 expression in HGPIN was two times higher than BPH, while in PRAD the expression of miR-155 was downregulated.
The mean expressions of miR-155 BPH were 1.57 \pm 1.33 , HGPIN $3.15 \pm 2.75$, and PRAD $1.27 \pm 1.45$. The difference in miR expression between the three groups was not significantly different with $p=0.14$. SOCS-1 mRNA expression was analyzed using PCR reverse transcriptase with internal control of betaActin mRNA. The expressions of SOCS1 mRNA in this study were not significantly different $(p=0.96)$, as shown in Figure 2. The average SOCS1/beta-Actin ratio in $\mathrm{BPH}$ was $2.4 \pm 0.89$, HGPIN was $2.3 \pm 0.95$, and PRAD was $2.43 \pm 1.06$.

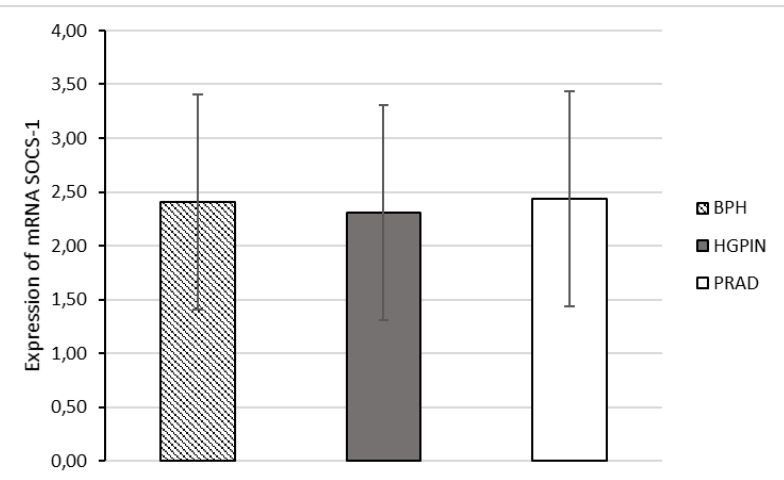

Figure 2. The ratio of SOCSI/beta-Actin in BPH, HGPIN, PRAD. Quantification of $m R N A$ band using ImageJ software.

To determine whether miR-155 and SOCS1 mRNA affected macrophages, a correlation analysis was performed using Pearson correlation tests. The results in Table 1 indicate that miR-155 has a significant negative correlation with SOCS1 mRNA $(p=0.02)$.

Table 1. Correlation between variable

\begin{tabular}{lll}
\hline Correlation & Correlation coefficient $(\mathbf{r})$ & $\boldsymbol{p}$ value \\
\hline $\begin{array}{l}\text { miR-155 to SOCS1 } \\
\text { mRNA }\end{array}$ & -0.47 & 0.02 \\
miR-155 to & -0.05 & 0.79 \\
macrophage & & 0.28 \\
\hline $\begin{array}{l}\text { SOCS1 mRNA to } \\
\text { macrophage }\end{array}$ & 0.22 & \\
\hline $\begin{array}{l}\text { Pearson correlation, } p \text { significant }<0.05 \\
\end{array}$
\end{tabular}

Percentage of macrophage population in BPH, HGPIN, and PRAD

Analysis of data using ANOVA obtained the mean percentages of macrophages in BPH $0.89 \pm 0.93$, HGPIN $6.03 \pm 1.68$, and PRAD 7.94 \pm 3.07 with $p=0.00$. The macrophage population between HGPIN and PRAD was not significantly different with $p=0.075$. 


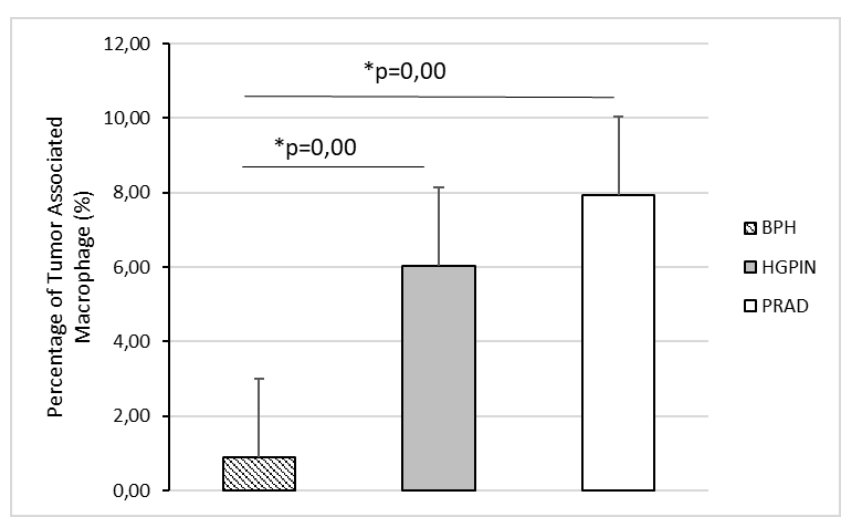

Figure 3. Percentage of macrophages in BPH, HGPIN, and PRAD. * $p<0.001$.
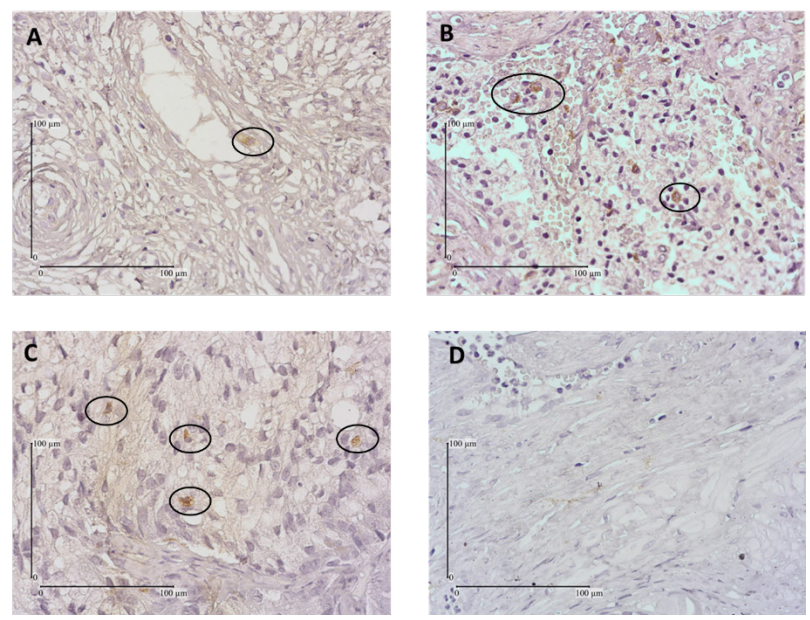

Figure 4. IHC staining, the macrophage is stained brown using an anti-CD68 antibody (in the circle), photomicrograph magnification - 400x, scale

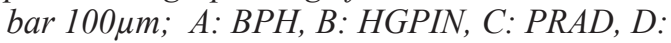
negative control without CD68 antibody

\section{DISCUSSION}

In humans, miR-155 is encoded by the miR155 gene in the $21^{\text {st }}$ chromosome, which regulates several biological processes including proliferation, invasion, apoptosis, in vitro or in vivo cell cycles, and inflammation. Changes in miR-155 expression induced by epigenetic changes related to oncogenesis and disease progression are observed in many cancers including PRAD and could be used as a carcinogenesis biomarker and in prognostic evaluation. ${ }^{13,14}$ In PRAD, 30 percent of epigenetic silencing regions are placed at the microRNA locus. Epigenetic mechanisms include deletion of microRNA genes, acetylation or methylation of microRNA promoters, alteration in transcription control, and defects in microRNA biogenesis. $^{14}$ MicroRNA-155 targets SOCS-1
mRNA and SHIP1 mRNA and increases activation of the AKT and interferon pathways. Decreasing SOCS1 mRNA increases the pro-inflammatory response of M1 macrophages by activating the JAK/ STAT pathways. The MiR-155 also manages M2 via CCL18, SERPINE, CD23, and DC-SIGN. ${ }^{15,16}$

In precancerous lesions, such as HGPIN tissue, our findings suggest that miR-155 is increased by two times as much as in BPH because non-carcinoma tissue can be induced by proliferation. The SOCS1 mRNA as a target for miR-155 decreased slightly. However, miR-155 has a significantly negative correlation with SOCS1 mRNA. High-grade PIN is characterized by cell proliferation in the ductus and prostate gland acini with cytological changes observed in PRAD including giant nucleus and nucleoli. ${ }^{10}$ Another study stated that miR-155 had a proliferation effect via annexin-7. ${ }^{17}$ The sharp increase in miR-155 expression could be due to cell proliferation, not inflammation, leading to cancer progression.

SOCS1 mRNA is a negative regulator of cytokine signaling which attenuates classical antigen signaling and T cell function. In general, the SOCS1 mRNA promoters have a STAT binding site and could be induced by the JAK-STAT pathways via proinflammatory cytokines such as IFN- $\gamma$, IL-6, IL-2, IL-4, and IL-7. ${ }^{18}$ In the regulatory process, SOCS1 mRNA can be targeted by other microRNAs such as miR-19, miR-30d, and miR-221-5p. ${ }^{19,20}$ Based on miRTarBase, SOCS1 mRNA has three binding sites for miR-155. MicroRNA and argonaute form RNA-induced silencing complex (RISC) which binds to the mRNA seed region which triggers translational repression, mRNA decay, and mRNA degradation..$^{21,22}$

Adenocarcinoma of the prostate is considered to have a significant relation with inflammation. Inflammatory stress can lead to gene instability, which in turn affects cell transformation, vascularity, apoptosis, and DNA mutations. Evidence suggests that in normal prostate glands, gland hyperplasia, and adenocarcinoma commonly coincide with inflammation. ${ }^{7}$ Therefore, the CD68+ marker is an important marker for pan macrophages. The CD68+ infiltration found in this study indicated that the percentages of macrophages in HGPIN and PRAD were significantly higher than those in BPH. Chronic inflammation that induces inflammatory stress could further stimulate angiogenesis, apoptosis, and gene instability. ${ }^{7}$ Macrophages play a role in cancer progression because more than $50 \%$ of tumor mass consists of infiltrated macrophages..$^{5}$ In this study, 
macrophages were significantly increased. To determine polarization, it is necessary to stain the M1 and M2 macrophages.Inaddition tomiR-155, severalmicroRNAs play a role in macrophage activity such as miR-125b and miR 19a-3p. Anti-tumor macrophage induced miR-125b overexpression by targeting IRF-4 mRNA, the promoter of M2 macrophages. Downregulation of miR-19a-3p increases STAT3 signaling leading to suppression of the immune system by macrophages. ${ }^{23}$

In conclusion, miR-155 plays an important role in macrophage polarization by targeting SOCS1 mRNA and inducing polarization of macrophages to M1 or M2 macrophages. In our findings, miR-155 and the percentage of pan macrophages in HGPIN were higher than in $\mathrm{BPH}$. These findings may be related to macrophage infiltration and increased cell proliferation in precancerous lesions. Interestingly, even though miR-155 indirectly regulates pan macrophage activity through SOCS1 mRNA expression, but in this study, SOCS1 mRNA was unlikely to play this role, while other microRNAs might play a role in the precancerous progression. These possibilities need further study.

\section{Acknowledgment}

This work supported by a research grant from Faculty of Medicine, Public Health, and Nursing 2018 (FKKMK-S2-0003) and Research Grant Program (PTP UGM, 1775/UN1/DITLIT/DIT-LIT/LT/2018) from The Ministry of Research \& Technology and Higher Education of Indonesia 2018. This work was conducted at the Laboratory of Anatomy, Molecular Biology Laboratory, and integrated laboratory of Faculty of Medicine, Public Health and Nursing, UGM, Yogyakarta.

\section{Conflict of Interest}

The authors who have taken part in this study declared that they do not have anything to disclose regarding funding or conflict of interest concerning this manuscript.

\section{REFERENCES}

1. Komite Penanggulangan Kanker Nasional. Pedoman Nasional Pelayanan Kedokteran Tata Laksana Kanker Prostat [Internet]. 2018 [Cited 2020 December 4] ; Available from: http://kanker.kemkes.go.id/guidelines read.php?id $=5 \&$ cancer $=11$

2. De Nunzio C, Presicce F, Tubaro A. Inflammatory mediators in the development and progression of benign prostatic hyperplasia. Nat Rev Urol. 2016;13(10):61326.

3. Al-dabbagh AA, Mohammad EJ, Jaffal WN. Is high grade prostatic intraepithelial neoplasia a risk factor for prostate cancer?- a local study. Open J Urol. 2018;8:1-7.

4. Shiao SL, Chu GCY, Chung LWK. Regulation of prostate cancer progression by the tumor microenvironment. Cancer Lett. 2016;380(1):340-8.

5. Weagel E, Smith C, Liu PG, O'Neill K. Macrophage polarization and its role in cancer. J Clin Cell Immunol. 2015;6(4):338.

6. Parisi L, Gini E, Baci D, Tremolati M, Fanuli M, Bassani B, et al. Macrophage polarization in chronic inflammatory diseases: killers or builders? J Immunol Res. 2018;2018:1-25.

7. Fujii T, Shimada K, Asai O, Tanaka N, Fujimoto $\mathrm{K}$, Hirao $\mathrm{K}$, et al. Immunohistochemical analysis of inflammatory cells in benign and precancerous lesions and carcinoma of the prostate. Pathobiology. 2013;80:119-26.

8. Savoca MP, Inferrera A, Verderio EAM, Caccamo D. Search for novel diagnostic biomarkers of prostate inflammation-related disorders: role of transglutaminase isoforms as potential candidates. Mediat Inflamm. 2019;2019:1-10.

9. Thomas MU, Messex JK, Dang T, Abdulkadir SA, Jorcyk CL, Liou GY. Macrophages expedite cell proliferation of prostate intraepithelial neoplasia through their downstream target ERK. FEBS J. 2020.

10. Zhou M. High-grade prostatic intraepithelial neoplasia, PIN-like carcinoma, ductal carcinoma, and intraductal carcinoma of the prostate. Mod Pathol. 2018;31:71-9.

11. Lin YH. MicroRNA networks modulate oxidative stress in cancer. Int J Mol Sci. 2019;20(18):4497.

12. Zhou D, Chen L, Yang K, Jiang H, Xu W, Luan J. SOCS molecules: the growing players in macrophage polarization and function. Oncotarget. 2017;8(36):60710-22.

13. Hamadi AY, Algehainy NA, Hamdi FY. Molecular implications of microRNA 155 in the pathogenesis of cancer molecular implications of microRNA 155 in the pathogenesis of cancer. int J Gen Can. 2014;1(3\&4):4655.

14. Kim WT, Kim W. MicroRNAs in prostate cancer. Prostate Int. 2013;1(1):3-9.

15. Davidsson S, Carlsson J. Prostate cancer and inflammation: the role of miRNAs. EMJ Oncol. 2013;1:56-60.

16. Curtale G. MiRNAs at the crossroads between innate immunity and cancer: focus on macrophages. Cells. 2018;7(12):1-25.

17. Cai Z, Chen Q, Chen Y, Gu Me, Zheng D, Zhou J, et al. MicroRNA-155 promotes the proliferation of prostate cancer cells by targeting annexin 7. Mol Med Rep. 2015;11:533-8.

18. Zhang J, Li H, Yu J, Wang SE, Ren X. Role of SOCS1 in tumor progression and therapeutic application. Int $\mathrm{J}$ 
Cancer. 2012;130:1971-80.

19. Hernandez AV, Bobbala D, Kandhi R, Khan MGM, Mayhue M, Dubois CM, et al. SOCS1 inhibits migration and invasion of prostate cancer cells , attenuates tumor growth and modulates the tumor stroma. Prostate Cancer Prostatic Dis. 2016;00:1-12.

20. Shao N, Ma G, Zhang J, Zhu W. MiR-221-5p enhances cell proliferation and metastasis through posttranscriptional regulation of SOCS1 in human prostate cancer. BMC Urol. 2018;18(14):1-9.

21. Ragusa M, Barbagallo C, Brex D, Caponnetto A, Cirnigliaro M, Battaglia $R$, et al. Molecular crosstalking among noncoding RNAs : a new network layer of genome regulation in cancer. Int J Genomics. 2017;2017:1-17.

22. Lin S, Gregory RI. MicroRNA biogenesis pathways in cancer. Nat Rev Cancer. 2015;15(6):321-33.

23. Kohlhapp FJ, Mitra AK, Lengyel E, Peter ME, Program S. MicroRNA as mediators and communicators between cancer cells and the tumor micro-environment. Oncogene. 2015;34(48):5857-68. 